\title{
UNPAID WORK PERFORMED BY YOUNGER MEMBERS OF HOUSEHOLD UP TO 26 YEARS IN SLOVAKIA
}

\author{
MARIANA POVAŽANOVÁa, ${ }^{\mathrm{a},}$ JÁN KOLLÁR ${ }^{\mathrm{a}}$, MARIÁN KIKA, \\ GABRIELA NEDELOVÁ ${ }^{b}$
}

mariana.povazanova@umb.sk,jan.kollar@umb.sk,marian.kika@umb.sk,gabriela.nedelova@umb.sk

${ }^{a}$ University of Matej Bel in Banská Bystrica, Faculty of Economics, Department of Economics, Tajovského 10, Banská Bystrica, Slovakia

${ }^{\mathrm{b}}$ University of Matej Bel in Banská Bystrica, Faculty of Economics, Department of Quantitative Methods and Information Systems, Tajovského 10, Banská Bystrica, Slovakia

\begin{abstract}
The paper deals with unpaid work in Slovak households whilst focusing upon unpaid work performed by younger members of the household. Studies of unpaid work of people up to 26 years are still not well documented in literature. The aim of this paper is twofold: First, it seeks to answer the question whether people with a lower-income status in Slovakia spend more time performing unpaid work in households in comparison to people with a higher-income status, and hence whether household income is an important determinant of unpaid housework performed by younger members of Slovak households. Second, the paper aims to determine also other factors that influence the volume of unpaid housework performed by younger members of Slovakia households. The results suggest that people in lower-income households in Slovakia spend more time in household labour than people in higherincome households. This applies to routine, non-routine as well as care household work. According to the results from a regression analysis, factors different from income are important determinants of household labour of younger members of Slovak households.
\end{abstract}

\section{Key words}

unpaid work, household, income, younger members up to 26 years, determinants of unpaid work

\section{JEL classification}

D13, J22

\section{Introduction}

A family or household is still recognized as important type of social system since it is one of the primary social group in every society ${ }^{1}$. The typical family (usually referred to as nuclear family) consists of parents and their children and fulfilled several irreplaceable functions e.g. economic, biological-reproductive, emotional and socializing. Such kind of family is at the centre of investigations in this paper. When raising their children, parents have the right to have a requirement for them and also have the right to demand fulfilment of those requirements in accordance with applicable family legislation. Household labor, such as food preparing, taking care of textile etc. is a natural part of family life in almost every household and often is very time consuming. From this point of view, stressing the role of household labor, household could be considered as a production unit. For this reason, a lot of research mainly in second half of 20th century, has been devoted to examining domestic work, its determinants and implications for different areas of life (Dúran and Heras, 2012). When we focus on provision of unpaid work in our society in multi-person households it is rather an

\footnotetext{
${ }^{1}$ Note: despite there being some difference between family and household, for the purposes of our analysis taking into consideration also research sample which is under consideration in the paper, we are going to use these terms interchangeably. Similarly, we are going to use the terms household labor, housework and unpaid work in households interchangeably.
} 
exception to find a household in which one household member carries out all household duties. When investigating different participation of household members in housework one can speak about the division of household labor. Much has been written about the gender division of household labor between partners / parents (Shelton and John, 1996; Coltrane, 2000). When children are included in analysis, they are usually on demand side since the presence of young children in a household creates a demand for parental housework time. But children not only demand housework, they also supply housework within the family. Hence research conceptualizing the domestic workload as the combined inputs of couples overlooks that family units include others who could contribute, including teenagers and young adults (Bonke, 2010). Children, teenagers and young adults usually do much less housework in comparison with their parents and therefore monetary value of their housework is not recognized. Rather, if they are employed, the value of their paid work is more often highlighted. On the other hand, non-financial value of younger members' work which is much more difficult to quantify is more often appreciated in families and in society as a whole.

In the following the focus is on children's supply of housework which is not well documented in literature. Since in Slovakia children of different age are living with their parents, we focus on people up to 26 years old.

Apart from the above-described view on housework, there is another one dealing with the household resources. Many goods and services should be consumed in the household in order to meet certain needs of household members. Some of them are output of household members' unpaid housework, e.g. cooked dinner, washed clothes etc. A lot of goods and services, which household members are producing and then consuming themselves, are offered by the market as well, so households can buy them, instead of doing them by their own. The process of replacing unpaid household production with market substitutes is known as domestic outsourcing (Bittman et al., 1999). And so in provision of certain goods and services household members are facing at least two choices: either secure desired good or service on their own or buy it, e.g. either cook the dinner by themselves, or go to dine in the restaurant. The first mentioned choice is dealing with the implicit costs of household members' work, the other deals with explicit money costs. It is reasonable to assume that lower-income households are outsourcing less in comparison with the higher-income households simply because they can't afford it. With regard this in economic theory there is formulated so-called household resources argument, which says that finances influence the volume of outsourcing. The higher the household income is, the more of domestic services are used (Bittman et al., 1999) and vice versa, the lower the household income, the fewer the volume of outsourcing. In such cases, household members in lower-income households will carry out more housework and thus save their money by reducing their explicit costs. Such households would also be expected to have a greater involvement of younger household members in housework, especially in routine housework. Although the Slovak Republic is a small country, the income polarization of society is great.

The aim of this paper is twofold: first it seeks answer to the question whether people in lower-income households in Slovakia spend more time performing housework in comparison with people in higher-income households and hence whether the household income is important determinant of unpaid housework performed by younger members of Slovak households. Secondly (with focusing on household labor of younger members of Slovak household) the aim is to determine the other factors which are influencing the volume of household labor performed by younger members of Slovak households.

Since according to our best knowledge, there is no study in Slovakia which is focusing on deeper understanding of household labor performed by younger members, our paper brings certain contribution if the field of the economics of Slovak household. 
The rest of the paper is organized as follows: the next part presents the terminology used in the paper regarding the specific features of the subject of the analysis together with the brief literature review dealing with the division of housework and the role of children. In section 3 we discuss the sample selection and briefly describe the data and method used. In section 4, there is a presentation of the results; section 4 then concludes.

\section{Importance of household work performed by younger members up to 26 years in the household}

In household which consists of both parents and children, parents bear the main responsibility for running a household. But in order for a household to function properly, all members must help each other, cooperate and participate in its functioning. This applies also to the performance of household work and children's involvement in it. From this point of view, if one speaks about housework performed by children in household, it is useful to use the expression "help of children with the household work" thereby highlighting the fact, that main responsibilities in this area bear the other household members. By using the expression help with housework also emphasize the fact, that housework performed by children is certain supplement to the work done by someone else and that one does not mean heavy / difficult child labor.

Another aspect which should be elucidated is usage of terms children and younger members of households in the paper. In Slovak households there are children of different ages living with their parents. The youngest children, namely infants and toddlers are absolutely dependent on their parents. When children are young and learning life skills they are likely to do little housework, especially independently (Bonke, 2010). When children grow, they develop their abilities and skills and are able to do more (Craig et al., 2015) and many different things until they become completely independent from their parents. From the point of view of their parents - they are still their children regardless of whether they are 3 months or 3,13 or 23 years old.

On the other hand, in developmental psychology terminology, different terms are used when looking at different age groups of children, stressing the life stages of psychological development. In the paper children from 0 to 26 years old are included in the analysis. It is obvious that they differ in their abilities and hence their contribution to housework in household will be different. For this reason we prefer to use expression younger members of households. However, relation between age and amount of household labor performed by younger members which is reflecting different abilities of young people considering their age is incorporated in analysis.

It is beneficial for everyone in the household when younger members are involved in housework. A household is in a sense a team. To make the team work well, everybody in the household should cooperate. There are some important aspects which should be borne in mind when considering and interpreting the results of the analysis focusing on participation of younger household members on housework. Reichel (2008, p. 185) elaborated functions of the family in more detail, and so highlighted many important aspects in which help of younger members of the family with housework can be seen. He distinguishes socioreproductive, cultural-reproductive, biological-reproductive, economic, therapeuticallynursing and educational and defensive functions of the family.

Such breakdown encourages the extension of the primary view on family, and thus of what is being done in it, and hence it is able to consider the participation of young members in household activities. When children are helping at home from early childhood, they learn not only to receive but to give and to put their share in the whole performed work (Call et al., 1995). Housework help is an opportunity to express support to the family and its members, 
since family is a place of interest, fellowship and care for the others. Housework help is a chance to learn new and useful working, communication, social and managerial skills which can be utilized later in everyday and professional life; it is an opportunity to see, perceive and feel the benefits of individual members of family. Housework help is an important means of development of:

- personal qualities such as, self-control, self-discipline, reliability, autonomy,

- socio-psychological skills such as empathy, willingness towards others, being helpful at home and then outside the family, common communication as well as communication in difficult situations, perceiving the needs of others (Rende and Prosek, 2016).

- Development and training of attitude and relationship toward work is also very important. The results considering the unpaid work also suggest, that the performance of unpaid work represents in many cases an educational model and is also associated with the traditions of the household (Kika and Martinkovičová, 2015). And so is it stimulating to know, whether the performance of household work by younger household members is also associated with household work of their parents.

Several competing explanations of the division of unpaid work in household have been offered in literature dealing with the unpaid work. While the names may vary across studies (Coverman, 1985), one can usually meet with three alternative hypotheses, both in economic theory or sociology, namely the time-availability hypothesis, relative resources approach and the gender-role ideology hypothesis (e.g. Bianchi et al., 2000; Coltrane, 2000). Time availability theory suggests that couples allocate time in unpaid work on the basis of spouses' relative hours in the paid labor market and the amount of housework to be done (Bianchi et al., 2000; Coverman, 1985). The relative resources hypothesis argues that allocation of housework reflects the power between men and women: the level of relative resources partners bring to relationship determines how much work in household is performed by each partner (Coverman, 1985). The gender perspective or the sex role ideology hypothesis (Coltrane, 2000) argues that housework is a symbolic enactment of gender relations and explains why there is not a simple trade-off between time spent in unpaid and paid work among men and women.

Despite that presented theories were formulated in order to explain the division of household labor between partners, they can serve as a good theoretical background for investigation the housework performed by younger members of households, namely the timeavailability theory and gender role ideology hypothesis. When taking into consideration gender-role ideology hypothesis, there is a large body of research stressing the gendered patterns of children's of housework. Researchers have identified behaviour modelling as major mechanism of gender role reproduction and characterized gender socialization as a contextually embedded process ( $\mathrm{Hu}, 2015)$. On the other hand, time availability theory suggests, that people allocate time in housework on the basis of relative hours in the paid labor market and the amount of housework to be done. If younger members of households are involved in housework by helping their parents with household duties, according to this theory, they will devote more time to domestic work if parents spend more time in paid work (Blair, 1992) which means that children's household work is inversely related to their parents' time at home and positively related to the need for their work. Especially number of hours spent by women / mother in paid labor according to this theory seems to be important determinant. It is because household work remains highly segregated and predominantly a women's responsibility (e.g. Shelton and John, 1996; Coltrane, 2000), mainly in routine housework which are among the most time-consuming activities. In general, the more a mother in a dual-parent household works outside of the house, the more her children will work at home. 
The number of children and their birth order are also assumed to have impact on the supply of work (Bonke, 2010). It is reasonable to assume that there is positive relationship between the number of siblings in a family and the time a child spends on housework.

We have formulated the following hypotheses for a more thorough understanding of the issue. In line with preceding discussion we first hypothesize that more unpaid work is done in lower-income households, than in higher-income households. Second, we hypothesize that household income affects the amount of time spent by younger members of household in housework. In households where income is lower, young household members will help more. Third, we hypothesize that amount of housework performed by younger members of household increases with their increasing age. Next, we hypothesize that in households in which more housework is done younger members of household will help more. Finally, we hypothesize that in households the amount of time a woman spend in paid work is important determinant of younger members' involvement in housework.

\section{Data and methods used}

The data for these analyses were collected in 2018 within the project VEGA 1/0621/17 carried out at Faculty of Economics, Matej Bel University in Banská Bystrica, Slovakia using a questionnaire. Unit of analysis was a household, defined as a group of people who shares the same budget. The research sample consists of 1819 individuals within 732 households. The questionnaire was representative by the sex, age and education of the respondents. The survey was conducted in Slovak households in April-May 2018. The uniqueness of the survey is that it provides aggregated data that cannot be obtained from available official statistics. The questionnaire consisted of 8 parts, or Modules, the aim of which was to find out more information about time allocation of Slovak households (e.g. structure of housework, selected characteristics of paid work and commuting to and from work, attitudes towards parenthood, etc.) both on household level and on microeconomic characteristics of individuals. For the purposes of our analysis, we restricted the sample to the households in which at least one person under the age of 26 is living and parents are older than 27 years. After these adjustments, we end up with the sample of 448 households and 663 people under the 26 years. Data for analysis are taken from the I. Modul containing questions related to sociodemographic characteristics as well as from the II. and III. Modul. Each person of household was asked to indicate the approximate number of hours per week that he/she normally spends on performing domestic activities in the household he lives in and also for any other household. Categories of household work were adopted from HETUS methodology. Because some activities, such as gardening, are done only a few months per year, respondents were also asked to indicate how many months during the year they performed the given activity. By asking such a question to all household members, we were able to collect unique data about housework activities of all household members.

In this study, we focus on three groups of activities:

- routine housework - food management (including food preparation, baking and preserving, dishwashing), household upkeep (including cleaning dwelling and garden), making and care of textiles (including laundry and ironing),

- non-routine housework - gardening, pet care and tending domestic animals, repairs of dwelling, shopping and services and house construction and renovation,

- childcare.

There are various methods of evaluation of low-income households in the economy. Several characteristics of the household are considered before they are identified as lower income household. One of decisive criterion is the number of household members, upon which the boundaries for the characterization of low-income households are based. Since in 
our analysis we examine unpaid work in various households, we chose the median net monthly disposable income per household member in the Slovak republic for 2018 as a criterion for defining low-income households. A household with a lower net disposable income than $600 €$ per member is considered to be a lower-income household. This approach is from our point of view, the most suitable when examining the relationship between unpaid work and net household income.

In order to find answer to the question whether lower-income households are devoting more time to performance of household labor, the Mann-Whitney test was used since the underlying data could not be expected to follow a normal distribution. The testing was carried out on the significance level 0.1 .

With regard to determination of factors influencing the volume of household labor performed by younger members of Slovak households, the multiple regression analysis was used. The multiple linear regression analysis is a statistical analysis technique, which is one of the most commonly used methods in studying the relationship between a dependent variable and multiple independent variables. A dependent variable is modelled as a function of several independent variables with corresponding coefficients, along with the constant term.

In our analysis two dependent variables capture the volume of involvement of younger household members in housework. The first is average number of hours per week that household members up to 26 years reported that they normally spent on performing routine unpaid housework (RUW). The second dependent variable is average number of hours per week that household members up to 26 years reported that they normally spent on performing non-routine unpaid housework (NRUW).

The choice of independent variables follows from previous discussion and formulated hypothesis. The following seven possible influencing factors were determined for both the routine as well non-routine housework: number of children under 26 years $(\mathrm{NCH})$ in the household; average age of children under 26 years (AACH); type of dwelling (TD); average net monthly household income (AMI); average number of hours per week in paid work spent by man (PWM); average number of hours per week in paid work spent by woman (PWW); a measure of whether at least one member of household under 26 years is employed for pay work outside the home either full time or part time $(\mathrm{WCH})$ was included as dummy variable. The last included variable is different in the first and second model. The first model investigates the routine housework of younger members, household average hours spent on unpaid work for the whole household in routine activities (RH) is included as explanatory variable, while in second model average hours spent on unpaid work for the whole household non-routine activities $(\mathrm{NH})$ is included. In the interpretations of the next section, the emphasis is placed only on the sign of estimated coefficients since there is a risk of some relevant explanatory variables being omitted from the analysis, but what certainly can be trusted is the signs of the coefficients.

\section{Results}

Based on data, the largest percentage of men (14.3) as well as women (16.7) has a net monthly income between 701 and $800 €$.

As is obvious from Table 1 which provide descriptive characteristics of research sample, double-earner model of households is typical for analysed group of households. The median of the average weekly time in the main paid work of men is 45 hours and in the case of women 40 hours. Despite the fact that approximately equal percentages of men and women are at the same income intervals, our data show that men have higher net monthly income compared to women, which is standard not only in Slovakia. 
Table 1: Descriptive characteristics of research sample

$\begin{array}{lc}\text { Number of households } & 446 \\ \text { Average net disposable monthly income of household } & 1,463 € \\ \text { Average net disposable monthly income per household member } & 402 € \\ \text { Number of children under } 3 \text { years in households } & 76 \\ \text { Number of children from } 4 \text { to } 6 \text { years in households } & 74 \\ \text { Number of children from } 7 \text { to 15 years in household } & 212 \\ \text { Number of children from 16 to 18 years in household } & 46 \\ \text { Number of children from 19 to 26 years in household } & 255 \\ \text { Total number of children under 26 years in households } & 663 \\ \text { Percentage of households living in a flat } & 41.5 \% \\ \text { Percentage of households living in a family house } & 58.5 \% \\ \text { Average weekly length of routine unpaid work in hours per households } & 36.1 \text { hours } \\ \text { Average weekly length of non-routine unpaid work in hours per households } & 26.8 \text { hours } \\ \text { Average length of routine unpaid work in hours by household members up to 26 years of age } & 7.7 \text { hours } \\ \text { Average length of non-routine unpaid work by household members up to 26 years of age } & 6.4 \text { hours }\end{array}$

Source: the authors.

Our results show that households with lower incomes do more unpaid work than households with higher income. P-value using the Mann-Whitney test was 0.000 . We have confirmed this in all three types of examined groups of household work. We consider these results to be expected as lower income households are often forced to produce more goods and services for their own consumption and have fewer resources for outsourcing domestic tasks. At the same time, we also confirmed the expected result that younger household members are more involved in routine labour housework in households with lower income. In the case of non-routine housework work, we did not confirm this link.

Table 2 shows the results of multiple regression analysis of routine housework performed by younger members of Slovak households. The value of the coefficient of determination $\mathrm{R}^{2}$ (which is not shown in Table 2) is 0.66 . Thus, the explanatory content of this model can be considered as good.

Table 2: The result of the multiple regression analysis for routine household work of younger members of Slovak households

\begin{tabular}{lccc}
\hline \multicolumn{1}{c}{ Model } & $\begin{array}{c}\text { Standardized } \\
\text { coefficient }\end{array}$ & Coefficient & t-statistic \\
\hline Constant & & 1.558 & -6.220 \\
Number of children under 26 years (NCH) & $0.284^{* * *}$ & 0.292 & 7.814 \\
Average age of children under 26 years (AACH) & $0.260^{* * *}$ & 0.068 & 4.055 \\
Type of dwelling (TD) & $0.058^{*}$ & 0.579 & 1.676 \\
Average net monthly household income (AMI) & -0.041 & 0.001 & -1.180 \\
Average number of hours per week in paid work spent by man (PWM) & -0.039 & 0.020 & -1.035 \\
Average number of hours per week in paid work spent by woman (PWW) & $0.124^{* *}$ & 0.019 & 2.911 \\
Routine Housework (HW) & $0.492^{* * *}$ & 0.015 & 13.147 \\
At least one member of household under 26 years is employed for pay & $0.168^{* *}$ & 0.951 & 2.872 \\
work outside the home either full time or part time (WCH) & &
\end{tabular}

Notes: $* * * p<.01 ; * * \mathrm{p}<.05 ; * \mathrm{p}<.1$.

Source: the authors.

The results of regression analysis for routine household work of younger members of households shows that explanatory variables: number of children under 26 years $(\mathrm{NCH})$ in the household; average age of children under 26 years (AACH); type of dwelling (TD); average number of hours per week in paid work spent by woman (PWW); a measure of whether at least one member of household under 26 years is employed for pay work outside the home either full time or part time ( $\mathrm{WCH})$ and average hours spent on unpaid work for the whole 
household in routine activities $(\mathrm{RH})$ significantly affect the volume of help with routine household work by younger members.

Despite some specific features, routine housework is normally performed in all households. Its difference in household is connected with its volume, quality and which member of the household performs it. For routine housework is typical, that it is repeated and very time-consuming. According to results in the table the more children under the age of 26 are there in the household, the higher the amount of housework that these children perform is.

As the average age of children under the age of 26 grow, their volume of household work increases as well. It is no surprising since with the increasing age, children are most likely to have more skills and experiences. Parents also usually delegate more responsibilities relating to the running of the household to older children. This consideration is consistent with Craig et al. (2015).

If a household lives in a house, younger members of the household help more than a in a household which lives in a flat. One possible explanation is that living in house is connected with more unpaid work and the demand for their work is thus higher. The more time woman / mother spent in paid work, the more children help with housework. This is in live with time availability theory as was explained in literature review section. In general, the more a mother in a dual-parent household works outside of the house, the more her children will work at home. Blair (1992) came up with similar results. It is therefore not surprising to find out that in households where a woman spends more time in paid work her performance of household work is substituted by younger members. It is kind of spill over between the members of the household, which we consider to be standard, as all of its members should participate in the functioning of the household.

The more routine housework is done in the household, the more is also done by young people and children under 26. Results of previous research suggest that respondents perceive the performance of unpaid work as an educational model. Similarly, research has confirmed that unpaid work is not always perceived as something negative, but a significant number of households perform it with pleasure (Kika and Martinkovičová, 2015). What is quite surprising for us is finding that the net average monthly household income is not significant variable when considering performance of routine household work by younger household members.

Table 3 shows the results of multiple regression analysis for non-routine housework performed by younger members of Slovak households. The value of the coefficient of determination $\mathrm{R}^{2}$ (which is not shown in Table 3) 0.718 is even higher than in previous model. Thus, the explanatory content of this model can be considered as good.

Table 3: The result of the multiple regression analysis for non-routine household work of younger members of Slovak households

\begin{tabular}{|c|c|c|c|}
\hline & $\begin{array}{l}\text { Standardized } \\
\text { coefficient }\end{array}$ & Coefficient & t-statistic \\
\hline Constant & & 1.386 & -6.220 \\
\hline Number of children under 26 years $(\mathrm{NCH})$ & $0.164^{* * *}$ & 0.261 & 5.036 \\
\hline Average age of children under 26 years $(\mathrm{AACH})$ & $0.228^{* * *}$ & 0.061 & 3.903 \\
\hline Type of dwelling (TD) & 0.026 & 0.527 & 0.813 \\
\hline Average net monthly household income (AMI) & 0.008 & 0.001 & 0.245 \\
\hline Average number of hours per week in paid work spent by man (PWM) & 0.047 & 0.018 & 1.431 \\
\hline Average number of hours per week in paid work spent by woman (PWW) & -0.001 & 0.017 & -0.021 \\
\hline Non-routine Housework (NW) & $0.627^{* * *}$ & 0.012 & 18.342 \\
\hline $\begin{array}{l}\text { At least one member of household under } 26 \text { years is employed for pay } \\
\text { work outside the home either full time or part time (WCH) }\end{array}$ & $0.122^{* *}$ & 0.847 & 0.021 \\
\hline
\end{tabular}

Notes: $* * * p<.01 ; * * p<.05 ; * p<.1$.

Source: the authors. 
From the table it is obvious, that with the growth in the average age of younger members of households, the volume of their non-routine household work is increasing. These types of activities are in many households associated with hobby activities (such as pet care or gardening activities) and sometimes requires special skills (necessary for such as equipment repair, house reconstruction and similarly). It can be assumed that older children have more skills and experiences and are able to be more helpful non-routine domestic activities, which also require greater responsibility compared to routine unpaid work. Our claim is e.g. in accordance with Cheal (2003). It is not surprising that the volume of non-routine work performed by parents also positively affects the performance of non-routine work by younger members of the household, which suggests the adoption of patterns of parents' behaviour.

\section{Conclusion}

The paper deals mainly with the issue of household work performed by younger household members up to 26 years of age. With regard to current research in this field abroad, it extends investigation also to the conditions of Slovak household and thus fills some gap in research in Slovakia. The results that provide a more detailed but still limited view on the running of the Slovak households.

We have found several findings that clarify determinants of total household work in Slovakia and also determinants of household work of younger household members. In accordance with the economic theory, we have confirmed the hypothesis that in the lowerincome households in Slovakia, the volume of household work performed by all household members is higher than in higher-income households for all examined categories of household labor. We assume that it is because lower income households are to a greater extent trying to provide goods and services for their own consumption since they have limited resources, they can use in order to outsource household work.

We have also confirmed the assumption that with the increasing average age of young people in households, their volume of domestic work is increasing. Quite surprising for us was finding that average household income is not significant determinant of household work of younger members of households. In accordance with time availability theory in households where women devote more time to paid work, younger members are helping more with routine households' works. This was not confirmed in the case of a man / partner in household. In the category of non-routine unpaid work has been confirmed that if parents do more non-routine household work, then their children also do more, which suggests the adoption of patterns of parents' behaviour.

Further advancement of research in this area would be possible in several fields. In the future, it would be useful to find out how the decision-making process in households is taking place, which results in the time allocation in households with regarding the help of younger household members. In the paper we have studied the results of the decision without examining the decision-making stage, which could further contribute to understanding the allocation of time and activities of the members of the Slovak households.

\section{Acknowledgements}

The paper was supported by the grant scheme VEGA No. 1/0621/17 "Decision-making of Slovak households about time allocation for paid and unpaid work and effect of household strategies on selected areas of the economy".

\section{References}

[1] Bianchi, S. M. et al. 2000. Is anyone doing the housework? Trends in the gender division of household labor. In Social Forces, 2000, vol. 79, iss. 1, pp. 191-228. 
[2] Bittman, M., Matheson, G., Meagher, G. 1999. The changing boundary between home and market: Australian trends in outsourcing domestic labour. In Work, Employment and Society, 1999, vol. 13, iss. 2, pp. 249-273.

[3] Blair, S. L. 1992. Children's participation in household labor: Child socialization versus the need for household labor. In Journal of Youth and Adolescence, 1992, vol. 21, pp. 241-258.

[4] Bonke, J. 2010. Children's housework - Are girls more active than boys? In Electronic International Journal of Time Use Research, 2010, vol. 7, iss. 1, pp. 1-16.

[5] Call, K., Mortimer, T. J., Shanahan, M. J. 1995. Helpfulness and the development of competence in adolescence. In Child Development, 1995, vol. 66, pp. 129-138.

[6] Coltrane, S. 2000. Research on household labor: Modeling and measuring the social embeddedness of routine family work. In Journal of Marriage and Family, 2000, vol. 62, iss. 4, pp. 1208-1233.

[7] Coverman, S. 1985. Explaining husbands' participation in domestic labor. In The Sociological Quarterly, 1985, vol. 26, iss. 1, pp. 81-97.

[8] Craig, L., Powell, A., Brown, J. 2015. Co-resident parents and young people aged 15 - 34: Who does what housework? In Social Indicators Research, 2015, vol. 121, iss. 2 , pp. 569-588.

[9] Cheal, D. J. 2003. Children's home responsibilities: Factors predicting children's household work. In Social Behaviour and Personality, 2003, vol. 31, pp. 789-794.

[10]Durán-Heras, M. A. 2012. Unpaid work in the global economy. Bilbao : Fundación BBVA, 2012. ISBN 978-84-92937-26-4.

[11] Hu, Y. 2015. Gender and children's housework time in China: Examining behavior modeling in context. In Journal of Marriage and Family, 2015, vol. 77, iss. 5, pp. 1126-1143.

[12]Kika, M. Martinkovičová, M. 2015. Neplatená práca v slovenských domácnostiach výskum, výsledky, súvislosti. In Sociológia, 2015, vol. 45, iss. 5, pp. 474-503.

[13]Reichel, J. 2008. Kapitoly systematické sociologie. Praha : Grada. 2008. ISBN 978-80-247-2594-9.

[14] Rende, R., Prosek, J. 2016. Raising can-do kids: Giving children the tools to thrive in a fast-changing world. New York : Penguine, 2016. ISBN 978-0698-15303-5.

[15] Shelton, B. A., John, D. 1996. The division of household labor. In Annual Review of Sociology, 1996, vol. 22, pp. 299-321. 